\section{An Ediacara-type fauna from South Wales}

DURING investigation of the geology of the area south of Carmarthen, South Wales, UK, an isolated small exposure of a finely inter-laminated mudstone and siltstone of possible volcanogenic origin was discovered. This lithology differs from those found hitherto in the Arenig and Old Red Sandstone rocks locally, and does not resemble any of the facies of the recently discovered Tremadoc rocks of the area ${ }^{1}$. Samples from this quarry were examined by $\mathrm{K}$. J. Dorning of Sheffield University for microflora, but yielded none. Late last year a few badly preserved diskshaped impressions, some $1 \mathrm{~cm}$ in diameter, were discovered. These were tentatively linked with the trace fossil Astropolithon by P. Crimes (Liverpool) and A. Seilacher (Tübingen), who both suggested that if the material proved

Fig. 1 In each case, scale bar equals $10 \mathrm{~mm}$. a, Cyclomedusa sp. $b$, Medusinites sp.
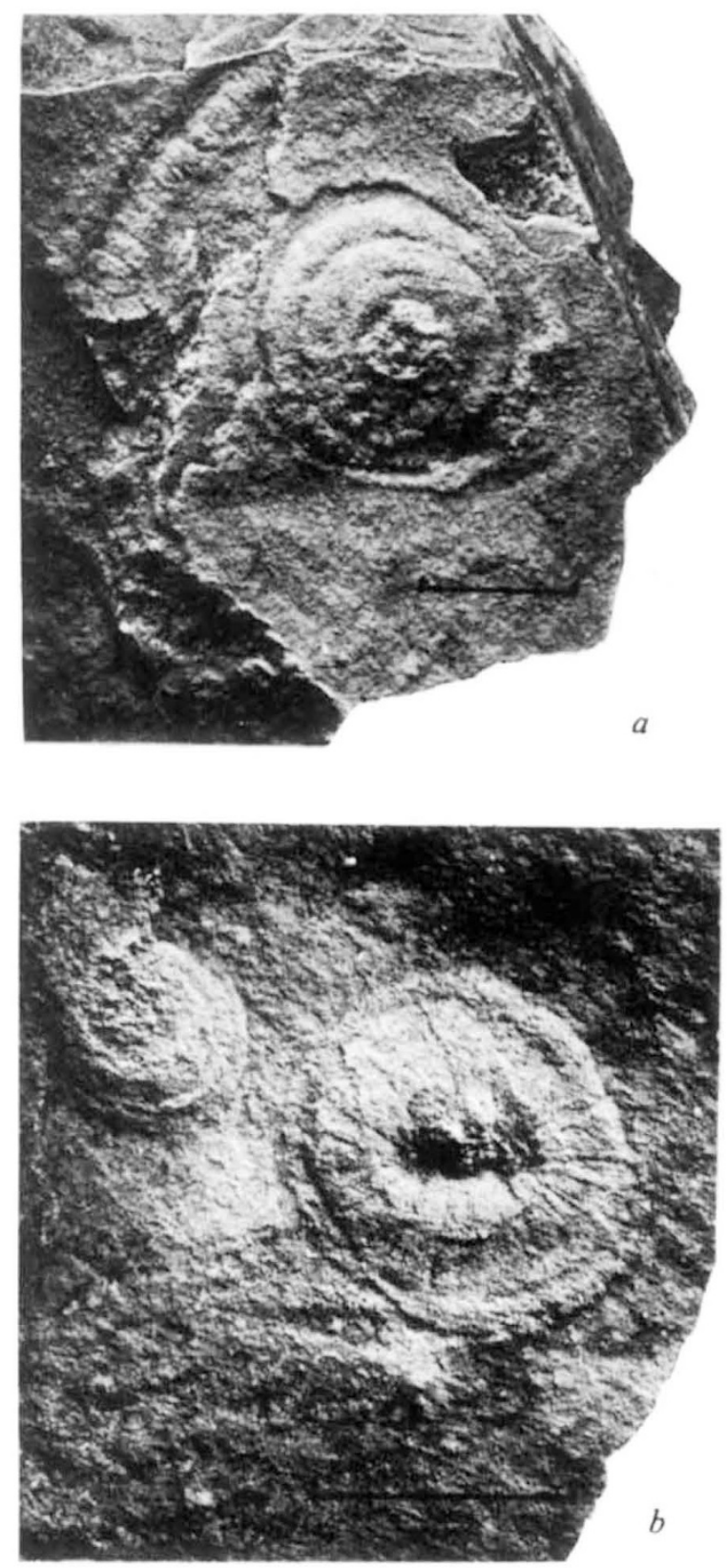

to be Astropolithon an Early Cambrian age would be indicated.

Further searches were made in the hope of finding material useful for dating. These have now yielded about 50 specimens including some better preserved material which is clearly of medusoid nature. A few of these specimens were subsequently examined by 1 . P. Crimes and by $\mathrm{R}$. Jenkins (Adelaide), who both confirmed the medusoid nature of the fossils and suggested that they included a form occurring in the late Precambrian Ediacara fauna of South Australia.

Amongst the material so far collected, the genera Cyclomedusa Sprigg 1947 (ref. 2) and Medusinites Glaessner and Wade 1966 (ref. 3) have been identified. The less well preserved material inoludes a form resembling the genus Tribrachidium Glaessner 1959 (ref. 4). Others cannot at the moment be related to any previously described forms.

The fauna clearly carries elements characteristic of the Ediacara fauna. Late Precambrian soft-bodied organisms are known from various areas of the world ${ }^{5}$ including Charnwood Forest, Leicestershire, $\mathrm{UK}^{6}$. In the Carmarthen region, however, until recently the earliest known rocks were of Early Ordovician (Arenig) age. The discovery of Tremadoc rocks there has led to a re-assessment of the age of the underlying rhyolites which are now presumed to be Precambrian. The rocks which have yielded the medusoids appear to rest on the rhyolites, although field relations in such a poorly exposed area are not clear.

No Cambrian rocks (if one excludes the Tremadoc) have hitherto been found in this area, and the possibility that the fauna is of Cambrian age cannot be excluded. It is felt, however, that the absence of any similar fauna in the Cambrian rocks of the St David's area (or elsewhere in Wales), argues against this, as does the apparently complete absence of metazoan skeletal material which would be most unusual for shallow water Cambrian sediments. Glaessner ${ }^{5}$ has given reasons for assigning a late Precambrian age to the Ediacara fauna. On palaeontological as well as regional geological grounds a similar age is suggested for this fauna.

Details of the location of the exposure and a description of the fauna will be published after a full investigation of the site.

JoHN C. W. COPE

\author{
Department of Geology, \\ University College, \\ Swansea, UK
}

Received 8 June; accepted 30 June 1977.

1 Cope, J. C. W., Fortey, R. A. \& Owens, R. M. Geol. Mag. (in the press).

2 Sprigg, R. C. Trans. R. Soc. S. Aust. 71, 212-224 (1947)

${ }_{4}^{3}$ Glaessner, M. F. \& Wade, M. Palaeoniology 9, B. Rec. S. Aust. Mus. 13, 369-401 (1959).

5 Glaessner, M. F. Bull. geol. Soc, Am. 82, 509-514.

6 Ford, T. D. Proc. Yorks. geol. Soc. 31, 211-217.

\section{Tachigalia versicolor is a suicidal neotropical tree}

Within a year of flowering in Tachigalia versicolor Standl. and Wms (Leguminosae-Caesalpinoideae) the leaves drop, the fruit is released and the tree dies. Reproduction occurs synchronously at intervals of several years in this large, much-branched, canopy tree species, but not all of the large individuals in the forest canopy flower and die at once. The species is known from the evergreen and semi-deciduous lowland forests of Panama, south-east Costa Rica and north-west Colombia. Except for a brief mention $^{1}$ of the Amazonian T. myrmecophila, I have found no previous reference to reproduction followed by death in Tachigalia (including Sclerolobium, an apparently congeneric $\left.\operatorname{tax}^{2,3}\right)$, nor in any other large, branched, dicotyledonous 